Commentary

\title{
Palimpsest Metaphor: Figures and Spaces of the Contemporary Project
}

\author{
Paola Viganò ${ }^{1,2}$ \\ ${ }^{1}$ Lab-U, École polytechnique fédérale de Lausanne, 1015 Lausanne, Switzerland; E-Mail: paola.viganò@epfl.ch \\ 2 Cultura del Progetto Department, IUAV University Venice, 30135 Venice, Italy
}

Submitted: 12 May 2020 | Accepted: 12 May 2020 | Published: 30 June 2020

\begin{abstract}
What are the consequences of the use of the palimpsest metaphor on the construction of the contemporary project? The metaphor casts criticism on the modern project and opens to the long-term (longue durée). The investigation of territorial rationalities brings to the fore these temporal dimensions and the organizational structures of space. Understanding territorial rationalities is inescapable to define the basis of any exploration of the future of territorial, urban-rural configurations. The metaphor of the palimpsest alludes to the meeting/clash between different times, endless modifications and transformations. Until the use of the support is not so serious as to question its very existence, directions, dynamics and, at times, fortuitous encounters interweave on its shriveled skin; forms of power and violence are measured there, which, in turn, will generate new conflicts. "Unintentional monuments" are places where this intensity of pure overlapping disconnected intentions become monumental and the substance of a project, revealing, celebrating and exposing their landscapes, as episodes of collective human and environmental history. The palimpsest as a figure in the contemporary project is not only a criticism of the modern space, but the expression of a change of direction in the design activity, of its social role and of the theories intended to support it: Design space in the second degree.
\end{abstract}

\section{Keywords}

contemporary project; landscape design; longue durée; palimpsest; territorial rationality; urban and territorial design

\section{Issue}

This commentary is part of the issue "Territories in Time: Mapping Palimpsest Horizons" edited by Chiara Cavalieri (UCLouvain, Belgium) and Elena Cogato Lanza (EPFL, Switzerland).

(C) 2020 by the author; licensee Cogitatio (Lisbon, Portugal). This article is licensed under a Creative Commons Attribution 4.0 International License (CC BY).

\section{Introduction}

There is great convergence on the figure of the palimpsest. Architects, urban planners, landscape designers, sociologists and naturally historians of the city all seem to agree on the usefulness of the metaphor of the territory as a palimpsest. But what are the consequences of the use of this metaphor on the construction of the contemporary project?

André Corboz's article "Le Territoire Comme Palimpseste" (Corboz, 1983) starts with a clear criticism of the tabula rasa of the modern project, in which the territory has no form or resistance; it does not need to be known or described, as the project will inevitably be strong enough to incorporate and rethink everything. Corboz belongs to that set of scholars and intellectuals who achieved detachment from the modernity of the grands récits, the death of which was celebrated by Francois Lyotard (1979) in La Condition Postmoderne. Rapport sur le Savoir, published just a few years before " Le Territoire Comme Palimpseste. » The Genevan scholar expressed there his crisis of confidence in an organizing, centralized and pervasive rationality. The metaphor of the palimpsest calls into question and radically denies the tabula rasa as an operating field on which the project unfolds.

\section{Territorial Rationality}

As stated by Corboz (1983, p. 16), ‘le territoire n'est pas une donnée': The territory is the result of a construction. The palimpsest intercepts it as an accumulation of physical and mental objects, theories, value systems and rationality that are not always consistent with 
each other. Together with the palimpsest, André Corboz took up the theme of the longue durée (long-term), introduced by Fernand Braudel who, from the 1920s, pondered the construction of a history of the Mediterranean (Braudel, 1949).

Taken prisoner on the Maginot line in 1941 and locked up in Mainz where he remained for five years, Braudel laid out and developed his positions on the Annales school and his long archive research within the hypothesis of a history placed outside of the events, a "repetitive" and "immobile" history. The longue durée represents the structure of history (Braudel, 1986). If there is a structure of signs reported in the territorial palimpsest, it is that defined by the longue durée which traces geometries of reference, horizons of meaning over the long-term, and reveals rationalities that do not perish-even if their material manifestations may appear incomplete or, in places, patchy. This structure sets the bounds for episodic, non-repetitive traces of the history of events that are set to disappear or become confused with others.

The metaphor of the palimpsest therefore casts criticism on the modern project and is open to the longterm and the longue durée, the idea of the territory as a place of slow and repetitive accumulation, a stratified space. It is interesting to note how this hypothesis formed in a scholar like André Corboz who did not believe in strong specializations. He was a hybrid researcher and self-professed historian who became an expert on each new theme he studied, acquiring an interdisciplinarity entirely unique to himself and omnivorous knowledge that, through his efforts, managed to highlight relationships invisible to most (Viganò, 1998), generating real transdisciplinary knowledge. Against specialization but not against vertical in-depth analysis, Corboz focused his research on the formulation of the hypothesis, an aspect that structures the entire path, without stiffening it, as the hypothesis is shaped by the research itself which, while it is being carried out, rewrites and updates it.

The long research on the territory of the Venetian "diffuse city" (Figure 1) we carried out in the last decades involved the development of exploratory moves around the idea of territorial rationality (Viganò, 2008), which brought to the fore the long-term (the long construction of water management infrastructure in relation to the topography and the nature of soil and subsoil over two thousand years) and the longue durée (the maintenance and revival of this system by the Benedictine monks in the Early Middle Ages, the Venetian Republic, and then and now by the reclamation consortia).

The two systems of "water and asphalt" and their logics of accessibility and water management emerge as organizational structures of space and society, inescapable elements of any interpretation of the widespread contemporary urban condition and at the basis of each exploration of the future of new urban-rural configurations. It is their slow transformation and, together, the destructive force of some events (for instance the route of a motorway that interrupts the flow of water from the slopes and the network of canals), or the evolution of techniques (from a surface irrigation network to its demise and burial) that become part of

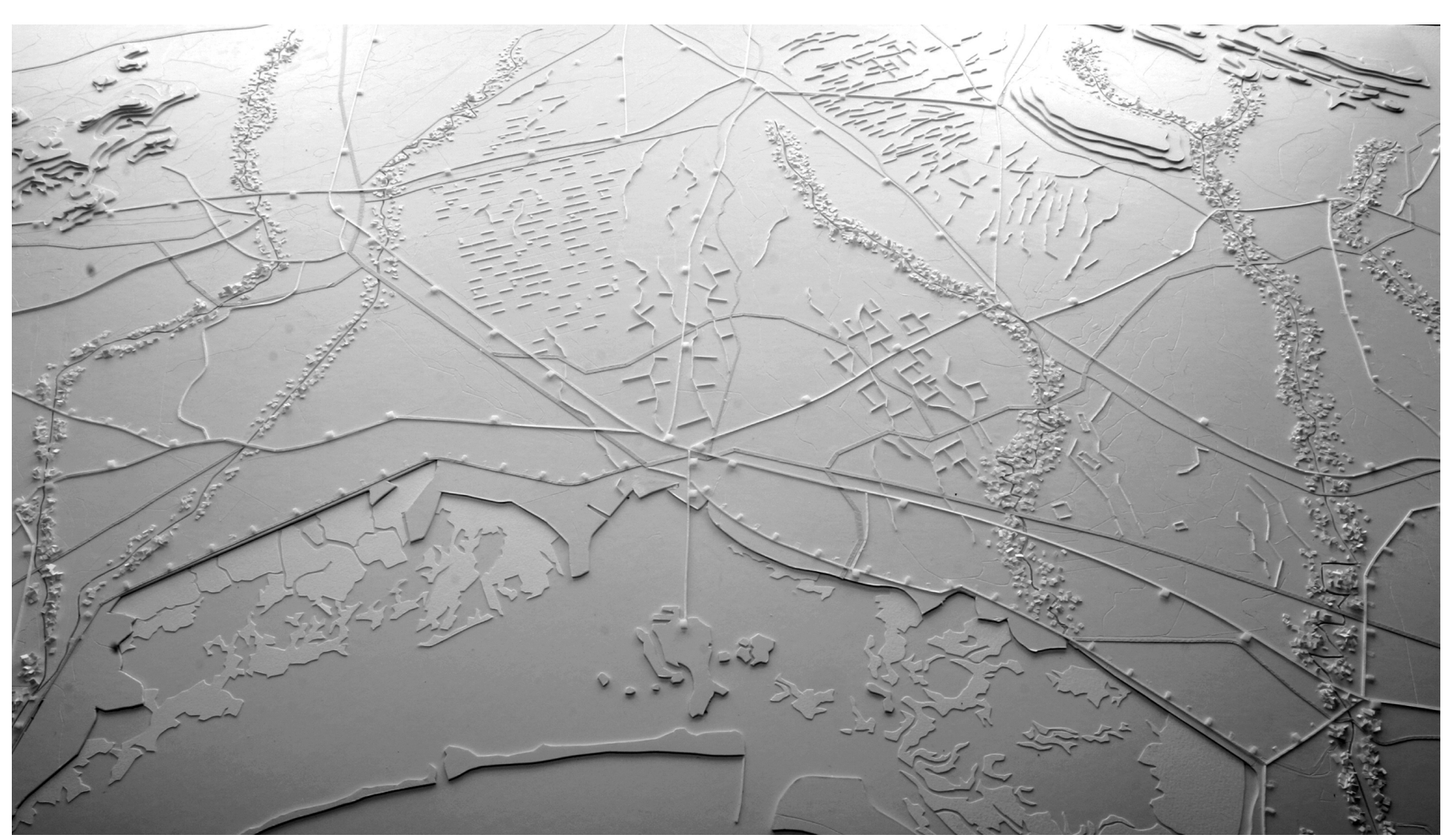

Figure 1. Isotropy as a figure of political rationality. Source: Viganò, Secchi, and Fabian (2016). Image credits due to B. Secchi, P. Viganò and IUAV PhD students at "Water and Asphalt," Venice Architecture Biennale, 2006. 
the construction of future territorial scenarios: of mitigation and adaptation to climate, economic and social change (Viganò, Degli Uberti, Lambrechts, Lombardo, \& Zaccariotto, 2009; Viganò et al., 2016).

Attention to infrastructural transformations (roads, drainage and irrigation networks, etc.), and the exploitation of resources (gravel extraction in the dry plain) provides an understanding of rationalities that are often invisible agents, gives hints about their material construction as imperfect territorial machines that are so rooted in our territories to become a second nature, as defined by Cicerone, new ecologies, capable of guiding, in this sense, the transformations over time. A transversal gaze is established by linking different temporal forms: the present-day context of the city territory and the thick territorial accumulation. The isotropic nature of these infrastructures, therefore, appears to be long-term, imbued with permanence, persistence and rationalities, rather than superficial chaos. Taking these considerations as a starting point, the vision is defined around the hypothesis that a project of isotropy can support climate change mitigation and adaptation strategies (from the "NoCar" to "more space for water"), reflecting the efficiency of a multitude of different and diffuse actions in opposition to the logic of large concentrated works.

\section{The Unintentional Monument: A Space in Common}

The palimpsest does not cease to undergo changes; the territory is a monument; it contains memories but it is not a tombstone. It does not cease to be transformed by confused and widespread alteration practices that urbanism assumes as its field of observation and design (Secchi, 2000). It is important to return to this point: The metaphor of the palimpsest alludes to the meeting/clash between different times, endless modifications and transformations, at least until use of the support is not so serious as to question the very existence of the palimpsest. Until that moment, directions, dynamics and at times fortuitous encounters will interweave on its shriveled skin, and forms of power and violence will be measured there, which, in turn, will generate new conflicts. They will come face-to-face on the palimpsest and will leave their traces mixed with the recursive practices of the longue durée. The territory is the result of countless projects and is, itself, the project subject: It raises, in this case, the question of responsibility for the interpretation/representation of the palimpsest, the burden of proof (Marquard, 1987) which accompanies any act of transformation (Jonas, 1979), and that is the inevitable counterpart of vision and hope (Bloch, 1959).

The palimpsest, metaphor of the stratified space in which relationships are crafted and reciprocal adaptation between the territory and population occur, gives rise to places where its intensity and depth become monumental. They were not designed with this purpose: They are unintentional monuments (Riegl, 1903). It is not the search for territorial rationality here that leads the de- sign exploration and eventually the construction of a new interpretation, but rather the effort is to explore the apparent lack of meaning and relationships between one layer and another. The real point of interest is the pure overlapping of disconnected intentions that becomes the substance of a project, providing legibility, revealing, celebrating and exposing their landscapes, making them recognizable as episodes of a collective human and environmental history. Stories of distant relationships and random intersections, such as that between Belgium, the Manhattan Project and the abundance of uranium in the Congo; the establishment in the Flemish region of Limburg, after the Second World War, of a nuclear center where engineers and scientists worked in a "model atomic village" (Atoomwijk) isolated among fields and forests but supported by the OECD. The village designed by the architects Wybauw and Thiran is a monument of modern architecture in Belgium. Nowadays, after it was almost completely abandoned (a renovation has started in 2019), the decision to accumulate all the country's nuclear waste at this site invites the community to reflect on the new position this site will assume in the national collective imagery. A monument-space.

The new nuclear information center in Dessel and its adjoining large park (see Figure 2) raised new concerns about the transparency of the project to store nuclear waste and the need for disclosure to near and distant populations. Once built, the center and the park will dialogue with the vestiges of the nuclear village, the Bochelt-Herentals canal (built in 1843 and extended in 1928), the sand extraction lakes, the regional cycle paths, and the industrial areas requested by the local community as compensation. Nonsensical relations and stories surfacing on the palimpsest, but they can actually be understood one by one, traces of histories in proximity to each other, like theatrical characters without a common discourse. The monument keeps the memory alive: for instance, controversial decisions such as the one to establish a function that will characterize the future for centuries to come in a place marked by a long history of agricultural production, industrial exploitation. The "park" is the space where these different environmental and cultural stories can be given a contemporary sense.

Alongside "intentional monuments" that commemorate an event to be preserved in the memory and monuments that through their capacity to stay the course of time ("age-value monuments") demonstrate the succession of the life cycles of buildings, the unintentional monument, according to Riegl, marks an instant that can be recognized in the development of human activity. The extension to environmental history and the long-term is a must in the case of the Dessel nuclear park which, for a long time to come, will bear witness to the new territorial condition, taking the role of a problematic "space in common," where to share contradictions for which we currently have no solution.

Marked by deforestation from the 5th century onwards, and by overgrazing and depletion between the 


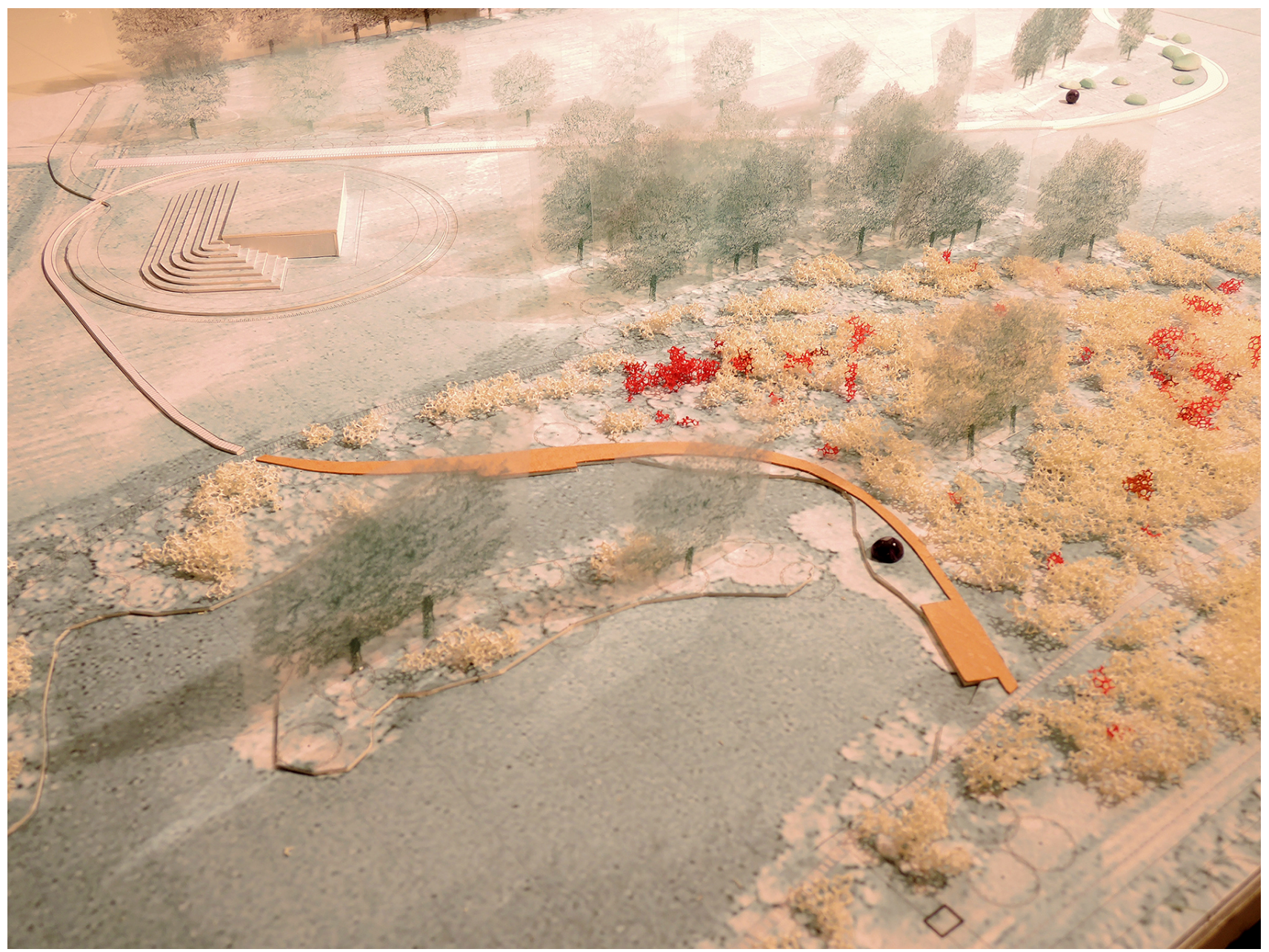

Figure 2. Dessel nuclear park. Sequences of landscapes: The wet heath. The new information center is being realized by Bovenbouw and ONO architectuur. Image credits due to the StudioPaolaViganò (P. Viganò, U. degli Uberti, V. Cox, J. de Vlam, A. Tamiazzo, C. van Maercke, K. Yoshida, Q. Zhang) and ARA (Dries Beys; 2017-ongoing project).

10th and 19th centuries (the Ferraris map of 1777 represents the sandy soils that were difficult to cultivate and the presence of heather), the large lawn in the center of the park will attest to centuries of fertilization, first natural and then chemical, which made a fairly infertile soil productive; it will be surrounded by pine reforestation, started in the 18th century for production purposes, and the extension of the spaces to reintroduce heather, added more recently. Fragments of landscapes close to low density and diffuse urban areas. The project does not envisage a return to an original and primal nature (as a form of compensation), represented in this context by the heather landscape, which would lead to the profound erasure (even at soil quality level) of the current situation, but the presentation of a multitude of histories (including that of the big rock music concerts held there thanks to maintenance of the large central lawn). This forms the basis for the new park narrative which work towards the maintaining of all memories, including that of the presence of nuclear waste. An unintended and unintentional monument. The park project, with the strip equipped with an area for playing and walks, adds a space that subliminally evokes images of the upturned soils of First World War battlefields, an image that settles on the palimpsest and redesigns it.

\section{Design Space in the Second Degree}

As a project, the land is semanticized. It can be parsed. It bears a name. Projections of all kinds are attached to it, transforming it into a subject. (Corboz, 1983)

A metaphor, although operative, does not guarantee the quality of the transformation introduced by the transformation. The palimpsest organizes our gaze, its capacity and interest in reading what remains visible of the previous texts. This is why, before Corboz, Gérard Genette used the metaphor to represent the hyper textual relationships and the hypertext (another well-known Corboz' metaphor, elaborated in Corboz, 1994) as the text that relies on and derives from a previous text through simple or indirect transformation operations (transformationimitation; see Genette, 1982). In Proust's Recherche du Temps Perdu, to which Genette dedicated an essay that 
appeared in the mid-sixties, the vast literary materials and the whole context are reworked and manipulated. Proust "is" the palimpsest (Genette, 1966). Writing, like many other artistic forms, lives on in the signs, words and sentences that accumulate on the palimpsest, becoming a refined game of revival and abandonment, decontextualized representation and over-interpretation, the re-invention of the relationships between the texts. The transparency of the last writing (which does not totally hide the previous ones) and the visibility of the texts that preceded it are typical of the palimpsest and emerge in the new text that incorporates and integrates them: literature in the second degree (Genette, 1982).

The palimpsest as a figure in the contemporary project is not only a criticism of the modern space, but an expression of a change of direction in the design activity, of its social role and of the theories intended to support it. Design space in the second degree, to paraphrase Genette, the palimpsest project reuses the previous structures and traces, whatever they may be; it is an expression of common languages and techniques, as well as a refined language and sophisticated technique. Starting from this ambiguous support, which does not legitimize any new discourse, but is rather an integral part of it, the contemporary project attempts to define new reasons for being that it can take responsibility for.

\section{Acknowledgments}

I thank the editors and I dedicate this text to André Corboz, who personally introduced each of his books to me.

\section{Conflict of Interests}

The author declares no conflict of interests.

\section{References}

Bloch, E. (1959). Das Prinzip Hoffnung [The principle of hope]. Frankfurt: Suhrkamp.

Braudel, F. (1949). La Méditerranée et le monde méditerranéen à l'époque de Philippe II [The Mediterranean and the Mediterranean world in the age of Philip II]. Paris: Librairie Armand Colin.
Braudel, F. (1986). Une leçon d'histoire [A lesson in history]. Paris: Flammarion.

Corboz, A. (1983). Le territoire comme palimpseste [The land as palimsest]. Diogène, 121, 14-35.

Corboz, A. (1994). Apprendre à décoder la nébuleuse urbaine [Learning to read the urban conurbation]. Cahier de l'Institut pour l'art et la ville, 8, 5-12.

Genette, G. (Ed.) (1966). Figures (Vol. 1). Paris: éditions du Seuil.

Genette, G. (1982). Palimpsestes. La littérature au second dégré [Palimpsests. Literature in the second degree]. Paris: Seuil. vJonas, H. (1979). Das Prinzip Verantwortung: Versuch einer Ethik für die technologische Zivilisation [The imperative of responsibility: In search of an ethics for the technological age]. Chicago, IL: University of Chicago Press.

Lyotard, J. (1979). La condition postmoderne. Rapport sur le savoir [The postmodern condition: A report on knowledge]. Paris: éditions de Minuit.

Marquard, O. (1987). Apologie des Zufälligen, Reclam [In defense of the accidental. Philosophical studies]. Oxford: Oxford University Press.

Riegl, A. (1903). The modern cult of monuments: Its essence and development. In N. S. Price, M. K. Talley, \& A. M. Vaccaro (Eds.), Historical and philosophical issues in the conservation of cultural heritage (pp. 69-83). Los Angeles, CA: Getty Conservation Institute.

Secchi, B. (2000). Prima lezione di urbanistica [First lesson on urbanism]. Bari: Laterza.

Viganò, P. (1998). André Corboz, connoisseur d'art et de villes [André Corboz, connoisseur of art and cities]. In P. Viganò (Ed.), Ordine sparso (pp. 11-32). Milano: Franco Angeli.

Viganò, P. (2008). Water and asphalt, the project of isotropy in the metropolitan region of Venice. Architectural Design, 78, 34-39.

Viganò, P., Degli Uberti, U., Lambrechts, G., Lombardo, T., \& Zaccariotto, G. (2009). Paesaggi dell'acqua/Landscapes of water. Pordenone: Risma Editrice.

Viganò, P., Secchi, B., \& Fabian, L. (Eds.). (2016). Water and asphalt. The project of isotropy. Zurich: Park Books.

\section{About the Author}

Paola Viganò is Professor of Urban Theory and Urban Design at the EPFL, where she directs the Lab-U and Habitat Research Center, and at IUAV, Venice. In 1990, together with Bernardo Secchi, she founded Studio and carried out projects in Europe up until 2014. She established StudioPaolaViganò in 2015. She received the Grand Prix de l'Urbanisme in 2013, the Ultima Architectuur Prize (Flemish Culture Award for Architecture) in 2017 and was awarded the "career" Golden Medal of Architecture by the Milan Triennale in 2018. She was Doctor Honoris causa at the Université catholique of Louvain in 2016. Her main recent publications include: The Territory of Urbanism (Routledge EPFL Press, 2016), The Horizontal Metropolis. Between Urbanism and Urbanization (Springer, 2018, co-edited with Martina Barcelloni Corte and Chiara Cavalieri) and The Horizontal Metropolis. A Radical Project (Park, forthcoming, co-edited with Chiara Cavalieri). 